\title{
CHALLENGES IN CAVE MONITORING AND SAMPLING - EXPERIENCES FROM SPELEOTHEM-BASED RESEARCHES IN CROATIAN CAVES
}

\author{
IZZIVI MONITORINGA IN VZORČENJA V KRAŠKIH JAMAH - \\ IZKUŠNJE PRI RAZISKAVAH SIG NA HRVAŠKEM
}

\author{
Maša SURIĆ ${ }^{1}$
}

\begin{abstract}
UDC 551.435.84(497.5)

Maša Surić: Challenges in cave monitoring and sampling experiences from speleothem-based researches in Croatian caves

Speleothem-based research aimed at the reconstruction of the Quaternary environment in Dinaric karst has been conducted in several Croatian caves. As the interpretation of the palaeoenvironmental signal archived in speleothems relies on identifying and understanding processes between atmosphere and cave precipitates, especially hydrological behaviour, cave monitoring is crucial. Despite relatively simple sampling and monitoring protocols, series of problems and complications has arisen, caused by different natural and technical reasons. Extreme weather events such as enormous precipitation, prolonged drought or snow drifts, each in their own way can cause sample loss. On the other hand, technical issues associated with equipment failures can lead to irretrievable data loss, and even biological threats, both man-induced and of natural origin, can occur. Although the later cannot be eliminated, as well as extreme weather, gained experience substantially helps to minimize negative effects. On the other hand, most of the technical issues are resolvable, and suggested solutions have been regularly implemented.
\end{abstract}

Key words: cave, karst, cave monitoring, sampling, Croatia.
Izvleček

UDK 551.435.84(497.5)

Maša Surić: Izzivi monitoringa in vzorčenja v kraških jamah - izkušnje pri raziskavah sig na Hrvaškem

$\mathrm{Z}$ namenom rekonstrukcije kvartarnega okolja v Dinarskem krasu že več let raziskujemo sige iz hrvaških kraških jam. Ker je interpretacija zapisov paleo-okolja v sigah močno odvisna od dobrega poznavanja in razumevanja procesov, ki povezujejo atmosfero, hidrologijo in sige, je zelo pomemben tudi monitoring recentnega jamskega okolja. Čeprav so postopki vzorčenja in meritev relativno preprosti, pri delu vseeno srečujemo številne probleme, povezane $\mathrm{z}$ naravnimi in tehničnimi vzroki. Izjemne vremenske razmere, kot so intenzivne padavine, suša in sneg, lahko povzročijo izgube vzorcev. Po drugi strani zaradi tehničnih izpadov delovanja opreme izgubljamo pridobljene podatke. Redkeje, a vseeno, lahko pridobivanje vzorcev in podatkov ogrozijo tudi jamske živali. Čeprav vseh teh pojavov ne moremo izključiti, lahko njihove negativne vplive minimiziramo, tehnične težave pa $\mathrm{v}$ veliki meri rešimo. $\mathrm{V}$ članku predstavimo težave in njihovo reševanje pri raziskavah $\mathrm{v}$ hrvaških jamah.

Ključne besede: jama, kras, jamski monitoring, vzorčenje, Hrvaška.

\section{INTRODUCTION}

Cave monitoring is a set of activities which include periodic or continuous measurements, recording and sampling of different environmental parameters, events and natural materials, respectively, aimed to obtain overall insight into the constant and varying conditions within the cave. An extensive description of recommended cave monitoring program is given in Toomey (2009), but usually only parts of the whole program are conducted depending on particular interests or needs. Cave monitoring is crucial for many purposes, e.g. for the assessment

\footnotetext{
${ }^{1}$ Department of Geography, Center for Karst and Coastal Research, University of Zadar, Ul. dr. F. Tuđmana 24 i, 23000 Zadar, Croatia,msuric@unizd.hr
}

Received/Prejeto: 01.01.2017 
of the contemporary microclimate settings for studies related to speleogenessis, cave biota, groundwater quality, speleotherapy, and for the sustainable use and management of the show caves (de Freitas 2010). Sometimes, show-cave monitoring is recommended not only for the health and safety purposes, but also for the conservation and management because of their heritage significance (Osborne 2002). Apart from the cave itself, monitoring programme should sometimes include associated landscapes as well (Toomey 2009). Namely, it is essential to understand importance of the seepage dynamics in karst environments and of the parameters governing speleothem growth (Sondag et al. 2003), since these processes in the karst system represent an important data base for speleothem interpretation (Riechelmann et al. 2011). Speleothems are, namely, recognized as valuable multiproxy climate archives which preserved records of the past climate from seasonal to millennia time scales. One of the benefits of the palaeoclimate related speleothem studies lies in the fact that the variations of isotopic composition of speleothem calcite provide valuable continental based indices of the past climate changes, with spatial distribution complimentary to those of marine and ice core records (Beddows et al. 2007). Rising importance of speleothem based studies was summarized by Henderson (2006) stating: "for paleoclimate, the past two decades have been the age of the ice core. The next two may be the age of the speleothem." After initial researches from 1960's on (e.g. Hendy \& Wilson 1968; Emiliani 1971; Hendy 1971), the increased interest resulted in worldwide coverage of cave and speleothem studies in palaeoenvironmental sense (e.g. Wang et al. 2004; Frisia et al. 2005; McDermott et al. 2011; Bar-Matthews \& Ayalon, 2011; Bajo et al. 2012; Fairchild \& Baker 2012 and references therein). In Croatia, systematic monitoring and sampling for the palaeoclimate reconstruction have commenced in 2000's through individual studies (e.g. Surić et al. 2010; Rudzka et al. 2012), and several different scientific projects, two of them being the subject of this paper - Reconstruction of the regional palaeoclimate change - speleothem records from the North Dalmatia (Croatia) (2012-2015) and Reconstruction of the Quaternary environment in Croatia using isotope methods (2014-2018).

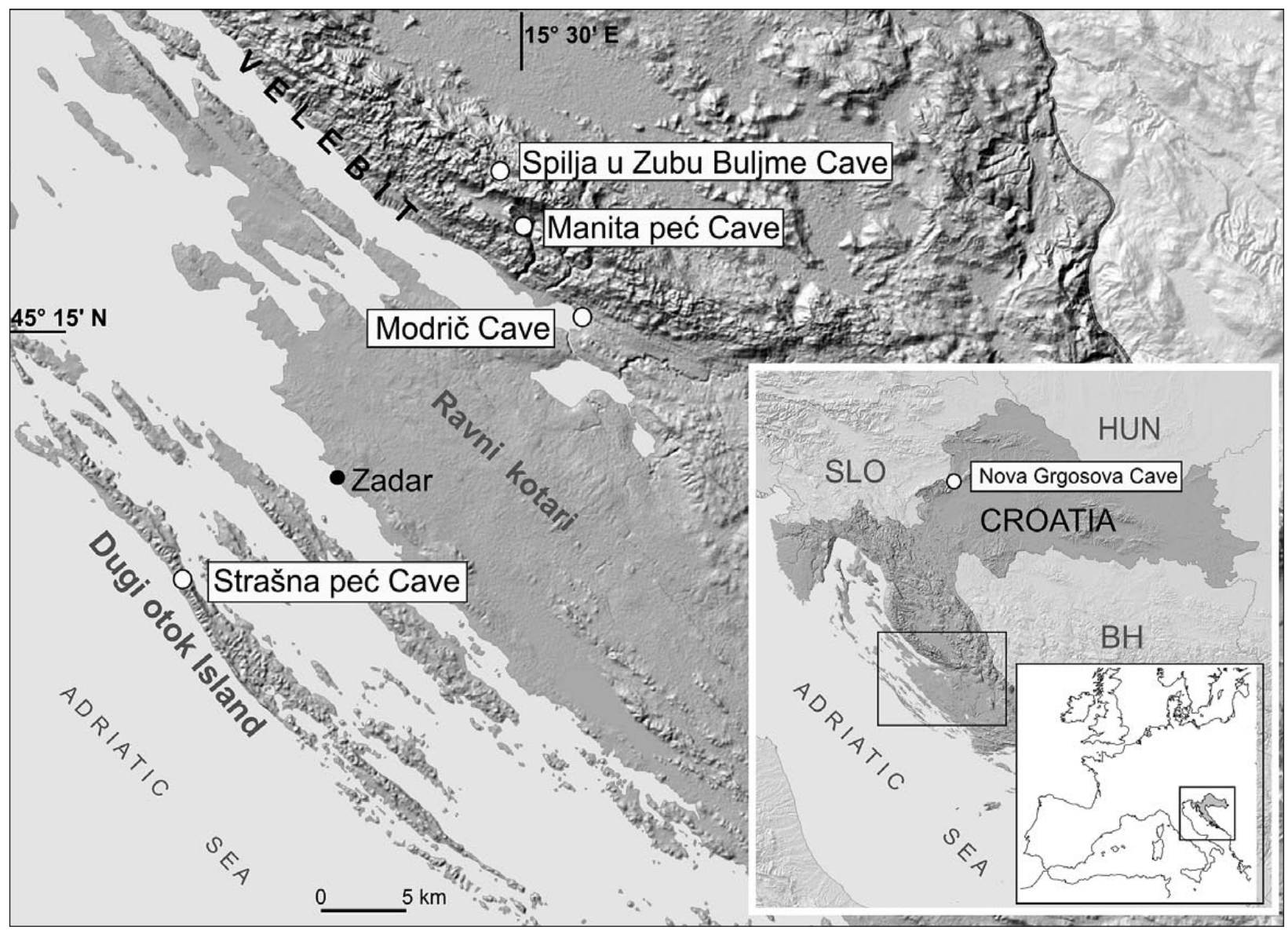

Fig. 1: Study area with locations of the four caves with encountered obstacles, and on inserted map location of Nova Grgosova Cave mentioned later in the text. 
This paper presents the experience gained from tackling with selection of the obstacles and complications encountered during the sampling and monitoring stage of the study undertaken in the Croatian part of the Dinaric karst from 2012 to 2016. It encompassed four caves: Modrič Cave (32 m a.s.l.), Strašna peć $(74 \mathrm{~m}$ a.s.l.), Manita peć (570 $\mathrm{m}$ a.s.l.) and Spilja u Zubu Buljme
(1250 $\mathrm{m}$ a.s.l.) on the transect from the Adriatic islands to the Velebit Mountain peaks (Fig. 1), different by altitude, dominated climate types, morphology, lithology etc. Given the different environmental settings, we have predicted and prepared for various obstructions, but yet some of them came unexpectedly.

\section{METHODOLOGY}

For the reliable palaeoclimate reconstruction from the speleothems, it is recommended to select and analyse stalagmite calcite precipitated at, or very close to, isotopic equilibrium with the cave dripwater $(\mathrm{McDermott}$ 2004) for which the characterization of hydrological and drip water regime is essential, together with the cave microclimate monitoring. Despite the growing number of monitoring campaigns, there is no unique 'white paper' prescribing the directives. Some of the general recommendations regarding overall monitoring are provided in Toomey (2009), Cigna (2002) proposes detailed instructions and offers some solutions of possible problems, while techniques and sensitivity/precision of measurements are compiled in Fairchild and Baker (2012, and references therein). On the other hand, some authorities (e.g. Cumberland Piedmont Network parks or Carlsbad Caverns National Park) provide exhaustive and detailed protocols arranged for their own purposes (e.g. Woodman et al. 2002 and Carlsbad Caverns National Park 2006, respectively). Everything aforementioned points that strategy, technique and frequency of measurements and sampling are site specific, depending on particular needs, so our monitoring was also customized.

We preformed air temperature and relative humidity (RH) monitoring inside and outside the caves, along with rain, dripwater and speleothem sampling. Given the sensitivity of the cave microclimate and instrumentation, battery-operated temperature and $\mathrm{RH}$ data loggers $\left(\mathrm{Hobo}^{\circ}\right)$ were carefully mounted, controlled and read out, so the outcome was uninterrupted data time series. Some of common threats such as battery failure or condensation on RH sensors were not encountered within this campaign, so this aspect of monitoring is omitted from the discussion. Composite water samples for stable isotope analyses have been collected monthly for 1-year period. Rainwater has been collected above each cave in 10-liter plastic cans with funnel protected by the plastic net to avoid clogging, and a layer of paraffin oil to hinder the evaporation of collected water. Precipitation amount data were obtained from the official meteorological stations (Croatian Meteorological and Hydrological Service 2017) due to their vicinities to the cave sites (from 3.7 to $18 \mathrm{~km}$ ) so their records could be considered as reliable. Low cost logging rain gauge Pluvimate ${ }^{\varpi}$ (Driptych 2017) which is convenient solution for the remote cave sites was avoided due to frequent clogging experienced during previous study (Rudzka et al. 2012).

Dripwater in the caves was also collected on the monthly basis under selected drip sites, some of which fed stalagmites sampled for the palaeoclimate reconstructions. Stalagmate ${ }^{\bullet}$ drip loggers were installed to record the response of the drip water discharge to the rain events on the surface, i.e. to characterize hydrological behaviour at the different drip sites. They were positioned in the funnel on the top of the bottle in order to collect the same water that was recorded. The bottles were carefully cut to prevent loggers from drowning when bottle fills. Drip logger deployment strategy i.e. mounting technique is recommended by producer, and is empirically founded. Loggers are suggested to be placed on sand-filled pad, aluminium foil, inside beaker or within the wire frame (Driptych 2017), depending on the cave properties.

In following chapters, certain obstacles that emerged despite all precautions are clustered into the groups regarding causes - extreme weather conditions, speleothem sampling limitations, technical issues and biological threats. Each problem is discussed and potential and applied solutions are presented. 


\section{UNEXPECTED ISSUES}

Given the latitudinal and altitudinal position of selected caves, generally, the maintaining cave monitoring should not have been an issue. Basically, the only concern was possibility that the highest mountain region would have been under the snow cover for some time, and that irresponsible visitors would have disturbed the equipment. For the latter, a warning note in five languages was provided, apparently successful. Though, other unexpected issues emerged, both of natural and technical origin.

\section{EXTREME WEATHER CONDITIONS}

A long-term (at least 1-year) monitoring usually has the main purpose of observation, measurement and subsequent assessment of the annual average values or average variations of particular parameters. However, extreme events caused by the severe weather conditions are not unusual and sometimes can substantially disturb the monitoring process. During the January 2013, Manita peć Cave area (570 $\mathrm{m}$ a.s.l.) received extreme amounts of precipitation (Fig. 2). It resulted in an overflow of the rainwater from the container together with the paraffin oil film which was supposed to protect the collected water from the evaporation and retain its isotopic composition. Thanks to the high relative humidity during such rain periods, the evaporation effect was minimized and, most probably, the lack of the oil film did not affect the water isotopic composition. The problem would arise if such scenario had occurred during the summer because

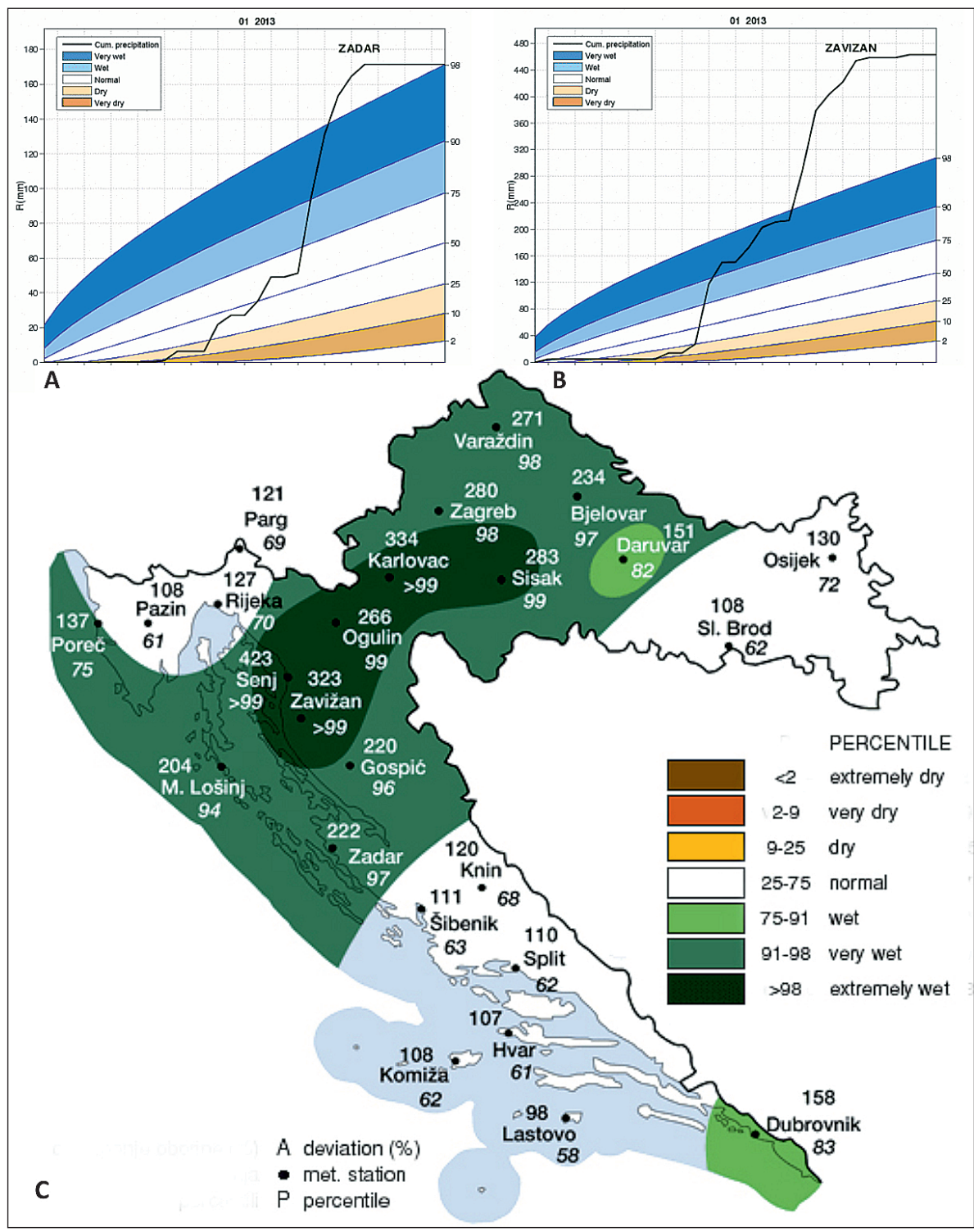

Fig. 2: Cumulative precipitation amount (mm) in January 2013 and theoretical percentiles (2, $10,25,50,75,90$ and 98 ) curves from the period 1961-2000 from the adjacent a) Zadar and b) Zavižan (Velebit Mountain) stations; c) Precipitation amounts expressed as percentages (\%) of 1961-1990 average for January 2013 (Croatian Meteorological and Hydrological Service, 2017). 


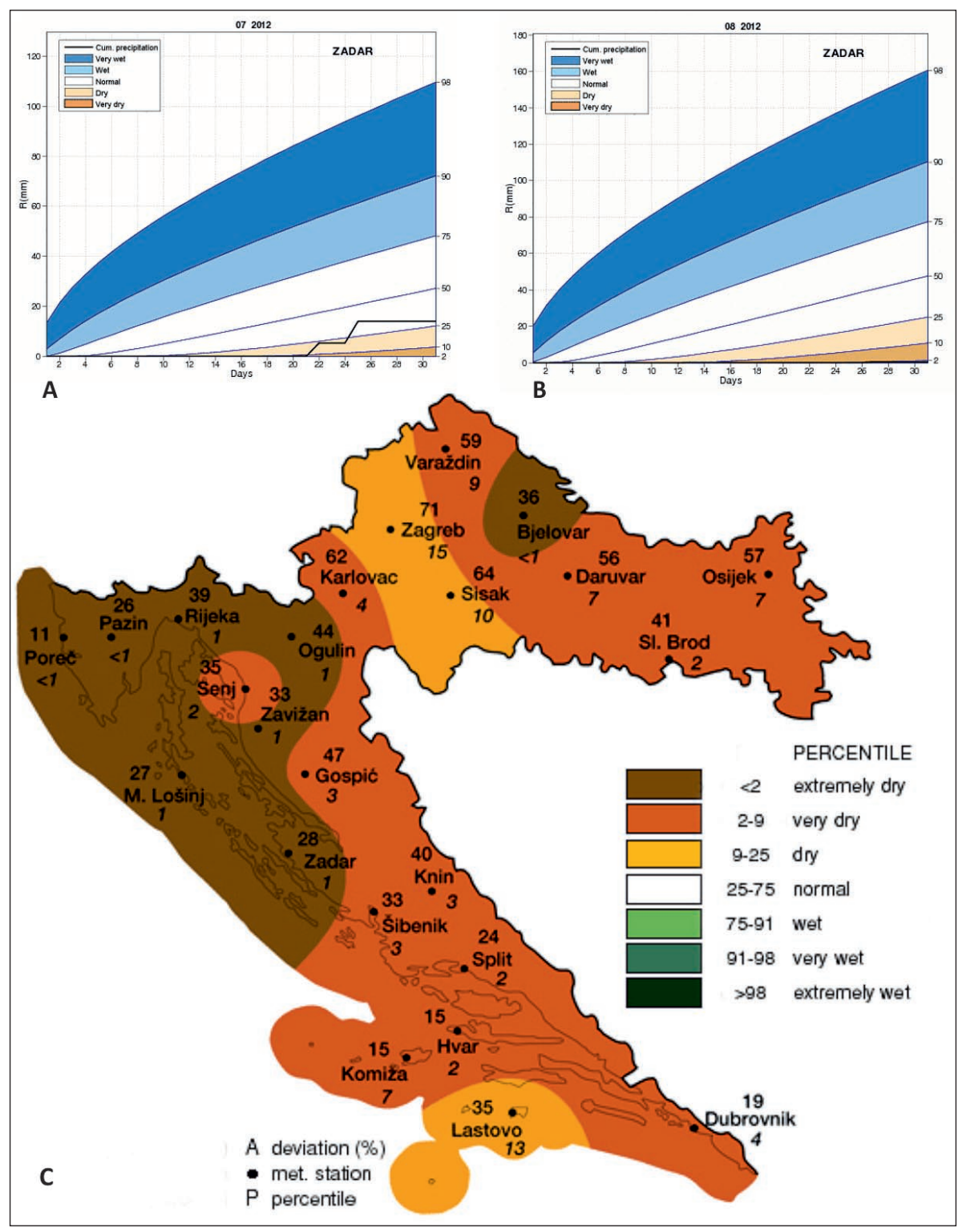

Fig. 3: Cumulative precipitation amount ( $\mathrm{mm}$ ) in a) July 2012 and b) August 2012, and theoretical percentiles (2, 10, 25, 50, 75,90 and 98) curves from the period 1961-2000 for the station Zadar; c) Precipitation amounts expressed as percentages (\%) of 1961-1990 average for Summer 2012 (Croatian Meteorological and Hydrological Service, 2017).

without the protective paraffin oil isotopic composition would have been significantly changed due to the kinetic fractionation associated with evaporation. What we could do to avoid the overflow is to utilize bigger water containers and/or smaller funnel, since the used 10-liter bottle with the $22.5-\mathrm{cm}$-diametar funnel fills up when the cumulative precipitations reaches the value of 250 $\mathrm{mm}$. Yet, smaller funnel might aggravate water collection during the extremely low precipitation episodes, which are in comparison to overflow more unfavourable. One of the possible solutions might also be a construction of system that enables overflow of the surplus water but retains the paraffin oil.

On other occasion, Strašna peć Cave area (Dugi otok Island, $74 \mathrm{~m}$ a.s.l.) suffered from severe drought during the summer 2012, uncommon even in littoral part of Croatia (Fig. 3), causing the lack of summer water samples. We have missed July 2012 rain water sample, but also cave dripwater samples from August and September 2012, due to the delayed response of the groundwater aquifer. Because of this setback we had to prolong water collecting to complete one-year rainwater samples with matching drip waters. The summer of 2013 had normal amount of precipitation in Strašna peć Cave area, sufficient for the continuous dripwater series. Because of such extreme natural-forced events, it is recommended and only applicable to extend the monitoring as long as possible in order to obtain statistically acceptable values.

As for the precipitation collection, we had expected the snow cover in the area of Spilja u Zubu Buljme Cave (Velebit Mt., $1250 \mathrm{~m}$ a.s.l.) and its duration from few days to several months. During the 2012/2013 win- 

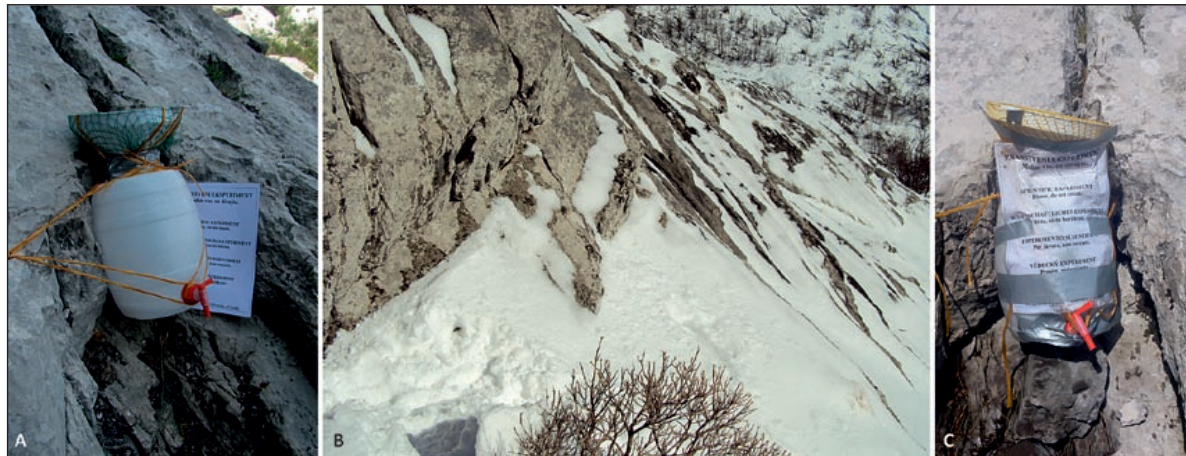

Fig. 4: Water collector in front of Spilja u Zubu Buljme Cave at $1250 \mathrm{~m}$ a.s.l.: a) after installing; b) under the snowdrift; c) damaged and repaired in situ (Photo: M. Surić and N. Lončar).

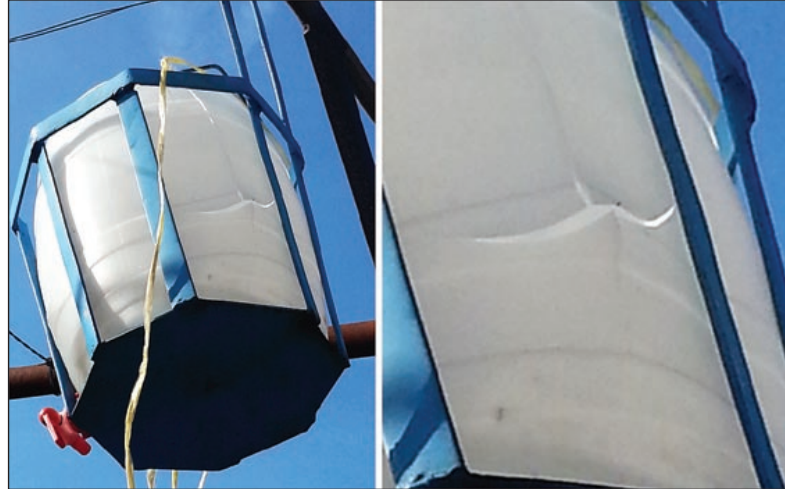

Fig. 5: Breakage of plastic water collector due to the long-term exposure to the direct sunlight (Photo: M. Surić).

ter, the water container (Fig. 4a) was completely buried by snowdrifts for two months (Fig. 4b). However, it had no effect on the sampling because instead of rain we collected the snow samples above the container which also had representative isotopic imprint. The cave dripwater was unfrozen, as well. But, the problem appeared after the snowmelt when we discovered mechanical damage which had to be fixed on the spot. Improvised solution shown in Fig. 4c preserved the samples until the next visit and replacement with the new container.

At fourth position, in Rovanjska village where the rainwater samples for the Modrič Cave region have been collected, long-term exposure to the direct sunlight resulted in degradation and breakage of plastic canister, fortunately above the collected water (Fig. 5), so the sample was not lost. The only preventions of this type of the problem would be shielding the canister from the direct sun radiation or even better, regular replacement of still functional equipment before the fatigue.

\section{SPELEOTHEM SAMPLING LIMITATION}

Apart from its mid-altitude position, Manita peć Cave has been chosen for this study for the abundance of speleothems of all kinds. Unfortunately, when it came to the very sampling it turned out that practically all stalagmites from suitable position within the cave had been broken

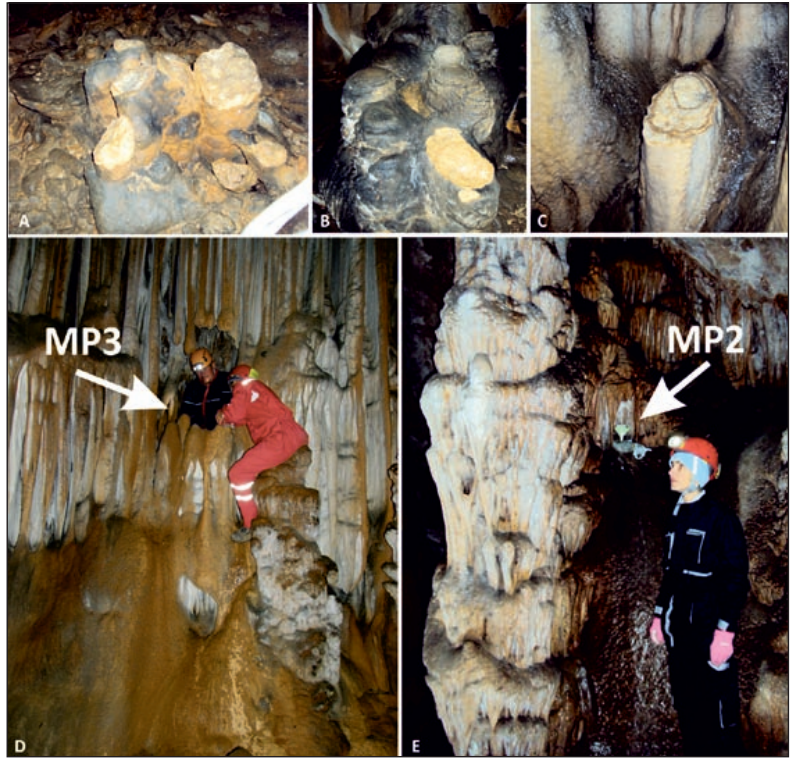

Fig. 6: Remnants of broken and removed stalagmites from Manita peć Cave $(a, b, c)$, and position of MP3 (d) and MP2 stalagmites (e) recovered for the analyses (Photo: M. Suric and R. Lončarić).

and dislocated from the cave by irresponsible visitors in the past (Figs. 6a, b \& c). Thus, we were challenged to find the stalagmites at very unusual locations, i.e. at the niches at the heights of $2 \mathrm{~m}$ and $3.5 \mathrm{~m}$ from the cave floor (Figs. 6d and e).

With the intention to resolve the most recent palaeoenvironmental changes, we aimed at the active stalagmites with relatively uniform drip rate. Apparently, after a single-day observation, we were misled by the 'stable' MP3 drip rate during that visit. Though, instead of 'stable' one, we had a fracture flow response of the MP3 drip site with discharge highly correlated with the rain events (Fig. 7). For the comparison, MP2 site had relatively low and quite stable discharge with only a weak response to the rain events, as requisited (Surić et al. 2017a). Luckily, subsequent stable isotope analyses showed that the major part of MP3 stalagmite grew under a stable conditions regarding the drip rate and isotopic composition. 


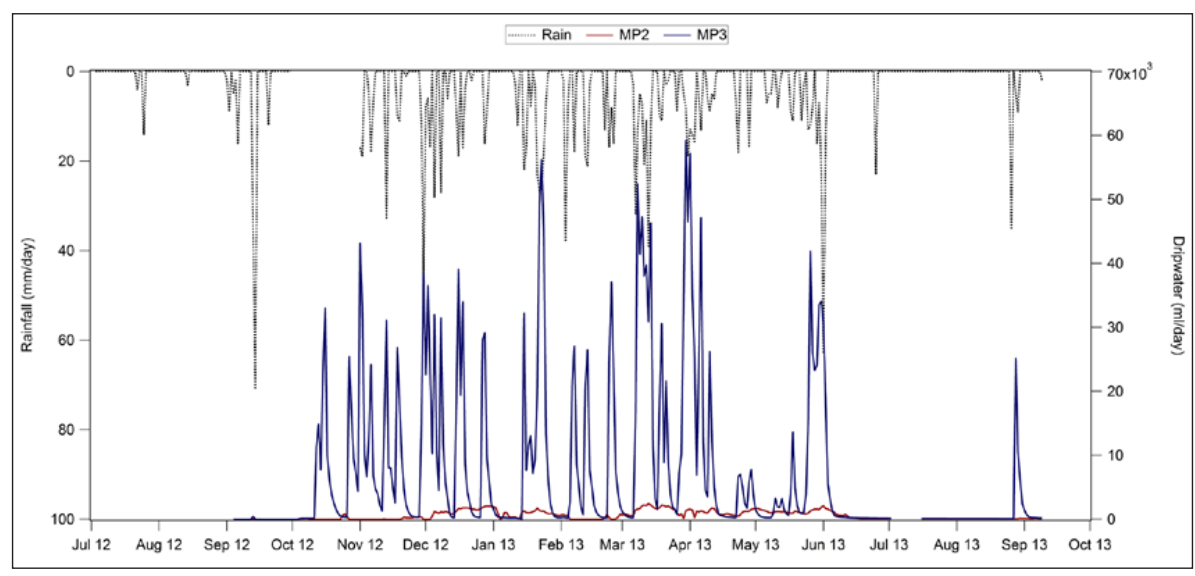

Fig. 7: Time series of the daily rainwater and drip water discharge for the drip sites MP2 and MP3 in Manita peć Cave. Note the fast response of the MP3 site to the each rain event, but also sudden decrease, and stable MP2 discharge regardless of the surface events. Precipitation data from the adjacent meteorological station Starigrad are provided by Croatian Meteorological and $\mathrm{Hy}$ drological Service (2017).

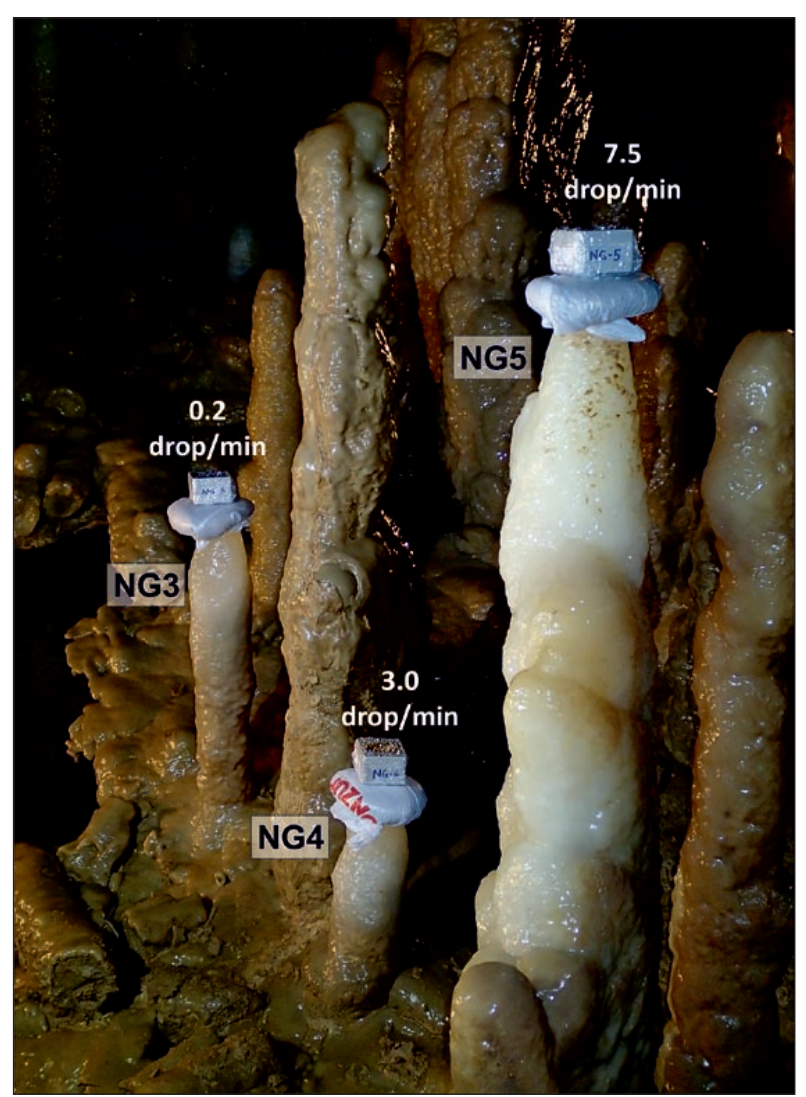

Fig. 8: Three equipped stalagmites potentially chosen for future palaeoclimate study in Nova Grgosova Cave, with associated discharge in drops per minute (Photo: M. Surić).

Only afterwards drip behaviour changed, probably due to the common shifts in percolation. Nevertheless, even with the contemporary fracture flow, oxygen and hydrogen isotope composition of drip water significantly differ from the rainwater composition in sense that the isotopic signal is well buffered, and very close to the MP2 values which is characterized with stable discharge (Surić et al. 2017a). Given the similarity with the average rainwater isotopic composition, water in the epikarst apparently stays long enough to homogenize without discernible fractionation.

Cave conservation is usually emphasized as an important issue, especially when it comes to the speleothem sampling (Lauritzen \& Lundberg 1999; Frapier 2008; Spötl \& Mattey 2012). So, in order to minimize destructive and random sampling of potentially unusable speleothems, in the subsequent palaeoclimate study in continental part of Croatia in Nova Grgosova Cave, we applied a different approach. Seven months before speleothem removing, three potential stalagmites have been equipped with wrapped drip loggers that have been placed on the plastic bags filled with sterile sand (Fig. 8). Those stalagmites were chosen primarily because they have been actively growing, and also for showing significantly different drip behaviour. Namely, at the moment of placing the loggers, we manually counted one drip every 8 seconds, 20 seconds and every 5 minutes, respectively. According to the afterwards recorded drip rate, only so-called NG3 stalagmite (left one in Fig. 8), the one with the most stable discharge (Surić et al. 2017b), was collected for the analyses with strong confidence that speleothem with such stable drip rate would provide an attenuated signal of rainwater isotope composition, and presumably spelean calcite deposited in isotopic equilibrium with the dripwater. Although this cave abounds in numerous well-developed stalagmites, our intention is always to minimize the damage by taking out only the most promising ones.

\section{TECHNICAL ISSUES}

Aforementioned drip rates were recorded by the drop counters Stalagmate ${ }^{\otimes}$ Plus Mk2b which record the acoustically generated electrical impulses of drops falling onto the lid of a watertight box (Driptych 2017). Stalagmate ${ }^{\circ}$ is able to count drops at rates of up to 5 drops/sec which in our case in Manita peć Cave appeared to be very convenient for MP3 fast-dripping episodes (Fig. 7). Another important device specification is sensitivity to record 


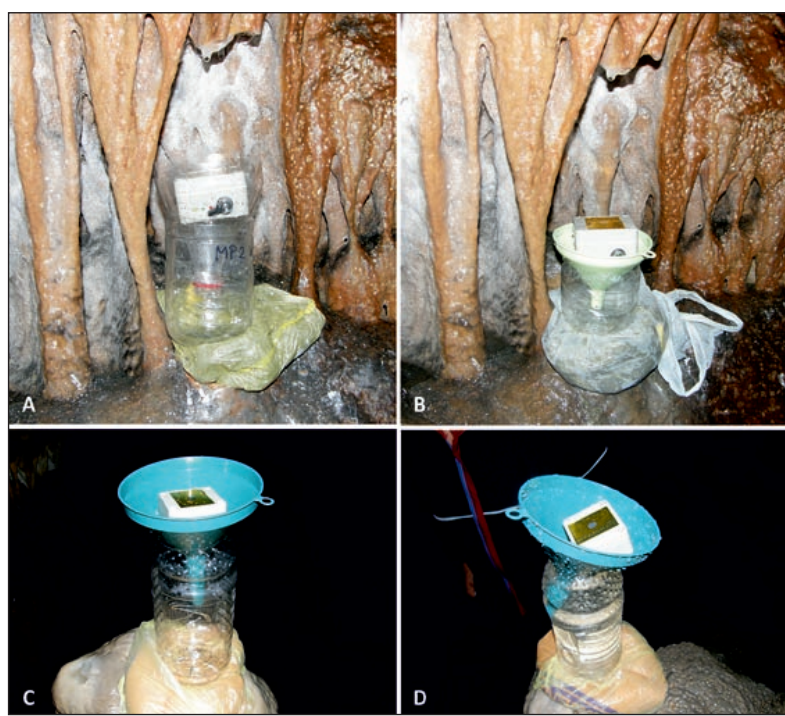

Fig. 9: Water collector and drip loggers in Manita peć Cave a) at the place of sampled MP2 stalagmite with distance from the drip site to logger being too short to record the hits, b) maximally shortened water collector and funnel; c) normal position of the drip logger under the drip site $M P 1, d)$ logger displaced from the center by the strong hits from ca. $7 \mathrm{~m}$-high MP-1 drip site (Photo: M. Surić).

$0.15 \mathrm{ml}$ drops falling from a height of as little as $20 \mathrm{~cm}$ (Driptych 2017). We encountered the problem of too low drip site after collecting MP2 stalagmite. Namely, due to the less than $20 \mathrm{~cm}$ distance between drip-site and the logger (Fig. 9a), drips could not have been registered so, as the only solution, we had to drastically shorten the water collector and the funnel (Fig. 9b). Besides, we also had the opposite situation - hits of the drops from very high drip site (ca. $7 \mathrm{~m}$ ) out of the lid center displaced the MP1 logger (Fig. 9d) from the central position (Fig. 9c) which then ceased logging, as well. The only prevention of this situation was very careful and precise positioning of the logger in a way that the drops hit exactly the center of the lid.
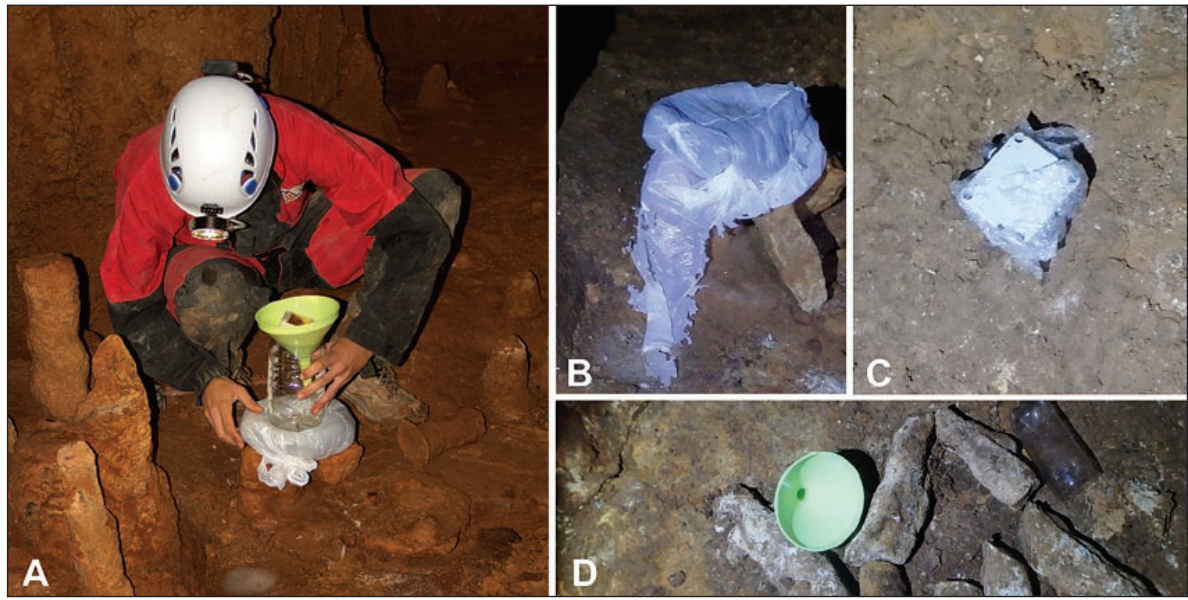

Another threat for recording the data, and also for very sensitive drip-logger, was extremely intensive calcification from the drip water onto the instrument, especially in Strašna peć Cave. We have regularly removed calcite from the lid, but at the end of measurement the rest of the logger was heavily calcified. Although we used that carbonate to obtain $\delta^{18} \mathrm{O}$ and $\delta^{13} \mathrm{C}$ values of modern calcite, better option would have been to wrap the logger in the transparent foil to prevent it from calcification, which we later applied.

Even before facing the first logger failures, we decided to systematically record drip rates by manually counting drips at each drip site during every visit, and eventually it turned out to be of great benefit. Few logger failures that occurred could have been conditionally bridged with the decent reliability by comparing the manually obtained drip rate from the recorded period and from the period of logger malfunction. Indirect confirmation of present but non-recorded dripping has been amount of the water accumulated in containers which has usually corresponded well to drip intensity.

\section{BIOLOGICAL THREATS}

Although Croatian karst hosts 316 terrestrial subterranean species (Croatian Biospeleological Society 2017), with almost $70 \%$ of them endemic for Croatia (Gottstein Matočec et al. 2002), not many of them pose as a threats for monitoring, mainly because of their smallness. However, there are several troglophiles that could endanger the equipment or data series, belonging to mammals of the order of bats (Chiroptera), rodents (Rodentia) and carnivores (Carnivora). So, after 23 months of trouble-free water collecting in deep interior of Modrič Cave (ca. $200 \mathrm{~m}$ from the entrance), the equipment was found scattered around and plastic bag chomped (Fig. 10). In this region, the most probable candidate, excluding bats, would have been stone marten (Martes foina), while other possible species like fat dormouse (Myoxus glis), Martino's vole
Fig. 10: Water collector and drip logger at the place of sampled MOD 32 stalagmite in Modric Cave: a) initial installing and dismantled equipment b) bitten sand-filled plastic bag, c) displaced drip-logger and d) funnel (Photo: M. Surić). 
(Dinaromys bogdanovi), snow vole (Chionomys nivalis), rock mouse (Apodemus mystacinus) (Tvrtković 2002) or even maybe a weasel (Mustela nivalis) usually do not reside so close to the coast (pers. comm. G. Lukač). As no action can be undertaken due to the nature protection, this risk will persist.

In Strašna peć Cave similar problem occurred. As already mentioned, water collectors together with drip loggers were placed on the sand-filled plastic bags used to level an uneven surface. During the second visit to the Strašna peć Cave (one month after placing the logger) the sand was scattered out of the bag, with risk of the whole equipment falling down. Small holes on the bag pointed to the presence of the bugs which were brought in with the sand of uncontrolled origin (from the city park). Such an introduction of the surface fauna into the cave is not acceptable for the ecological reasons, but we are convinced that the damage for the ecosystem has not been done. The sand was later replaced with the sterile one (from the store) and such procedure became an imperative. Alternatives such as wire mounting or aluminium foil could also have been employed, but sterile sand appeared as appropriate solution.

\section{CONCLUSIONS}

In spite of relatively undemanding monitoring and sampling protocols during the speleothem-based studies, we encountered a number of problems caused by natural forces, technical limitations of the equipment and partly by the human interference. Weather conditions such as severe summer drought, autumn precipitation extreme by amount and intensity, and winter snow drifts caused different setbacks, fortunately with no significant damage. However, these situations cannot be neither predicted nor avoided, so the best option would be to ensure at least two years for the monitoring purposes, and preferably more. Set of the technical issues that we have met during the determination of drip properties can be avoided by the cautious selection of the drip sites, but they are often predetermined by the suitable stalagmites which are going to be collected for the stable isotope and other analyses. As for the speleothem selection, it is preferred that the cave or part of the cave has not been accessible for visitors in the past, because the best speleothem material is usually damaged as in the case of the Manita peć Cave.

Along with collecting samples and time series data sets during the monitoring phase, a valuable experience was gained, and has already been implemented. Regardless of few disruptions, forthcoming results are expected to be fruitful, offering novel and genuine data and insight into palaeo- and contemporary environmental settings of the selected parts of Croatian karst. However, common saying amongst karstologists In karst, always expect the unexpected (Hamilton-Smith 2002) should never be neglected.

\section{ACKNOWLEDGEMENTS}

The overall collaboration, help and fruitful discussions with co-workers on the projects N. Buzjak, N. Lončar and R. Lončarić are gratefully acknowledged, as well as the field assistance of our colleagues N. Andačić, A. Ažić Potočnjak, M. Baričević, S. Buzjak, M. Buzov, F. Domazetović, I. Kostrenčić, J. Mijailović, M. Parica, F. Pehar, K. Prskalo, K. Samodol and B. Vukosav. I also thank the cave authorities: National park Paklenica staff with special gratitude to G. Lukač, then V. Šarunić, concessionaire of the Strašna Peć Cave and Grgos family, the concessionaire of Nova Grgosova Cave. Special gratitude goes to the Croatian Meteorological and Hydrological Service for the meteorological data and to
Ines Krajcar Bronić for useful advices. Neven Bočić and an anonymous reviewer are acknowledged for the revision that led to the manuscript improvement. These activities were part of the scientific projects Reconstruction of the regional palaeoclimate change - speleothem records from the North Dalmatia (Croatia) financed by University of Zadar and Reconstruction of the Quaternary environment in Croatia using isotope methods (HRZZ-IP-11-2013-1623) financed by the Croatian Science Foundation while Public Institution Green ring, Zagreb County supported researches in Nova Grgosova Cave. 


\section{REFERENCES}

Bajo, P., Drysdale, R., Woodhead, J., Hellstrom, J. \& G. Zanchetta, 2012: High-resolution U-Pb dating of an Early Pleistocene stalagmite from Corchia Cave (central Italy).- Quaternary Geochronology, 14, 5-17. DOI: http://dx.doi.org/10.1016/j. quageo.2012.10.005.

Bar-Matthews, M. \& A. Ayalon, 2011: Mid-Holocene climate variations revealed by high resolution speleothem records from Soreq Cave, Israel and their correlation with cultural changes.- The Holocene, 21, 1, 163-171. DOI: http://dx.doi. org/10.1177/0959683610384165.

Beddows, P.A., Schwarcz, H.P., Zhang, R. \& D.C. Ford, 2007: Cave drip monitoring as a foundation for better paleo-climate reconstruction.- In: Elliott, W.R. (ed.) Proceedings of the 2007 National Cave and Karst Management Symposium, $8^{\text {th }}-12^{\text {th }}$ October 2007, St. Louis. NCKMS, 204-211, St. Louis.

Carlsbad Caverns National Park, 2006: Cave and Karst Management Plan Environmental Assessment, dated 30 September 2006.- [Online] Available from: https://www.nps.gov/cave/learn/management/upload/cave_karst_ea_2006.pdf [Accessed $8^{\text {th }}$ July 2017].

Cigna, A.A., 2002: Modern trend in cave monitoring.Acta Carsologica, 31, 1, 35-54. DOI: http://dx.doi. org/10.3986/ac.v31i1.402.

Croatian Biospeleological Society, 2017: Cave fauna.[Online] Available from: http://www.hbsd.hr/ [Accessed $2^{\text {nd }}$ January 2017].

Croatian Meteorological and Hydrological Service, 2017: Precipitation data.- [Online] Available from: http:// www.klima.hr/ [Accessed $3^{\text {rd }}$ January 2017].

Driptych, 2017: High Precision Drip Monitoring.[Online] Available from: http://eswww.rhul. ac.uk/ mattey/private/driptych3/ [Accessed $8^{\text {th }}$ July 2017].

Emiliani, C., 1971: Last interglacial: Paleotemperatures and Chronology.- Science, 171, 3971, 571-573. DOI: http://dx.doi.org/10.1126/science.171.3971.571.

Fairchild, I.J. \& A. Baker, 2012: Speleothem Science: From Process to Past Environments.- Wiley-Blackwell, pp. 450, Chichester. DOI: https://dx.doi. org/10.1002/9781444361094.

Frappier, A.B., 2008: A stepwise screening system to select storm-sensitive stalagmites: Taking a targeted approach to speleothem sampling methodology.- Quaternary International, 187, 1, 25-39. DOI: http://dx.doi.org/10.1016/j.quaint.2007.09.042. de Freitas, C.R., 2010: The role and importance of cave microclimate in the sustainable use and management of show caves.- Acta Carsologica, 39, 3, 477489. DOI: http://dx.doi.org/10.3986/ac.v39i3.77.

Frisia, S., Borsato, A., Spötl, C., Miorandi, R., Villa, I. \& F. Cucchi, 2005: Climate variability in the South-Eastern Alps of Italy over the last 17.000 years reconstructed from stalagmite records.- Boreas, 34, 4, 445-455. DOI: http://dx.doi. org/10.1080/03009480500231336.

Gottstein Matočec, S., Bakran-Petricioli, T., Bedek, J., Bukovec, D., Buzjak, S., Franičević, M., Jalžić, B., Kerovec, M., Kletečki, E., Kralj, J., Kružić, P., Kučinić, M., Kuhta, M., Matočec, N., Ozimec, R., Rađa, T., Štamol, V., Ternjej, I. \& N. Tvrtković, 2002: An overview of the cave and interstitial biota of Croatia.- Natura Croatica, 11, 1, 1-112.

Hamilton-Smith, E., 2002: Management assessment in karst areas.- Acta Carsologica, 31, 1, 13-20. DOI: http://dx.doi.org/10.3986/ac.v31i1.400.

Henderson, G.M., 2006: Caving in to new chronologies.Science, 313, 5787, 620-622. DOI: http://dx.doi. org/10.1126/science.1128980.

Hendy, C.H., 1971: The isotopic geochemistry of speleothems-I. The calculation of the effects of different modes of formation on the isotopic composition of speleothems and their applicability as palaeoclimatic indicators.- Geochimica et Cosmochimica Acta, 35, 8, 801-824. DOI: http://dx.doi. org/10.1016/0016-7037(71)90127-X.

Hendy, C.H. \& A.T. Wilson, 1968: Palaeoclimatic data from speleothems.- Nature, 219, 48-51. DOI: http:// dx.doi.org/10.1038/219048a0.

Lauritzen, S.-E. \& J. Lundberg, 1999: Speleothems and climate: a special issue of The Holocene.The Holocene, 9, 6, 643-647. DOI: https://doi. org/10.1191/095968399666229065.

McDermott F. 2004: Paleo-climate reconstruction from stable isotope variations in speleothems: a review.Quaternary Science Reviews, 23, 7-8, 901-918. DOI: http://dx.doi.org/10.1016/j.quascirev.2003.06.021

McDermott, F., Atkinson, T.C., Fairchild, I.J., Baldini, L.M. \& D.P. Mattey, 2011: A first evaluation of the spatial gradients in $\delta^{18} \mathrm{O}$ recorded by European Holocene speleothems.- Global and Planetary Change, 79, 3-4, 275-287. DOI: http://dx.doi.org/10.1016/j. gloplacha.2011.01.005.

Osborne, R.A.L., 2002: Significance and monitoring,Acta Carsologica, 31, 1, 21-33. DOI: http://dx.doi. org/10.3986/ac.v31i1.401. 
Riechelmann, D.F.C., Schröder-Ritzrau, A., Scholz, D., Fohlmeister, J., Spötl, C., Richter, D.K. \& A. Mangini, 2011: Monitoring Bunker Cave (NW Germany): A prerequisite to interpret geochemical proxy data of speleothems from this site.- Journal of Hydrology, 409, 3-4, 682-695. DOI: http://dx.doi.org/10.1016/j. jhydrol.2011.08.068.

Rudzka, D., McDermott, F. \& M. Surić, 2012: A late-Holocene climate record in stalagmites from Modrič Cave (Croatia).- Journal of Quaternary Science, 27, 6, 585-596. DOI: http://dx.doi.org/10.1002/ jqs. 2550 .

Sondag, F., van Ruymbeke, M., Soubiès, F., Santos, R., Somerhausen, A., Seidel, A. \& P. Boggiani, 2003: Monitoring present day climatic conditions in tropical caves using an Environmental Data Acquisition System (EDAS).- Journal of Hydrology, 273, 1-4, 103-118. DOI: http://dx.doi.org/10.1016/S00221694(02)00362-1.

Spötl, C. \& D. Mattey, 2012: Scientific drilling of speleothems - a technical note.- International Journal of Speleology, 41, 1, 29-34. DOI: http://dx.doi. org/10.5038/1827-806X.41.1.4.

Surić, M., Roller-Lutz, Z., Mandić M., Krajcar Bronić, I. \& M. Juračić, 2010: Modern C, O, and H isotope composition of speleothem and dripwater from Modrič Cave, eastern Adriatic coast (Croatia).- International Journal of Speleology, 39, 2, 91-97. DOI: http://dx.doi.org/10.5038/1827-806X.39.2.4.

Surić, M., Lončarić, R., Lončar, N., Buzjak, N., Bajo, P. \& R. N. Drysdale, 2017a: Isotopic characterization of cave environments at varying altitudes on the eastern Adriatic coast (Croatia) - implications for future speleothem-based studies.- Journal of Hydrology, 545, 367-380. DOI: http://dx.doi.org/10.1016/j. jhydrol.2016.12.051.
Surić, M., Lončarić, R., Bočić, N., Lončar, N. \& N. Buzjak, 2017b: Monitoring of selected caves as a prerequisite for the speleothem-based reconstruction of the Quaternary environment in Croatia.- Quaternary International, In Press. DOI: http://dx.doi. org/10.1016/j.quaint.2017.06.042.

Toomey, R.S., III, 2009: Geological monitoring of caves and associated landscapes.- In: Young, R. \& L. Norby (eds.) Geological Monitoring: Boulder, Colorado. Geological Society of America, pp. 27-46, Boulder. DOI: https://doi.org/10.1130/2009.monitoring(02)

Tvrtković, N., 2002: Mammalia.- In: Gottstein Matočec (ed.) An overview of the cave and interstitial biota of Croatia. Croatian Natural History Museum, pp. 76-77, Zagreb.

Wang, X.F., Auler, A.S., Edwards, R.L., Cheng, H., Cristalli, P.S., Smart, P.L., Richards, D.A. \& C.C. Shen, 2004: Wet periods in northeastern Brazil over the past 210 kyr linked to distant climate anomalies.- Nature, 432, 740-743. DOI: http://dx.doi. org/10.1038/nature03067.

Woodman R.L., Jernigan J.W., Carson B.C. \& B.J. Moore, 2012: A Protocol on Sampling Designs and Methodologies for Selective and Adaptive Monitoring in Caves of Air Temperature, Relative Humidity, and Cross-Sectional Air Velocity throughout the Cumberland Piedmont Network.- National Park Service, Report number: Natural Resource Report NPS/ CUPN/NRR-2012/491. 